\title{
EFEKTIVITAS BAHAN AJAR IPA BERBASIS INKUIRI TERBIMBING (BAIPABIT) UNTUK MENINGKATKAN KEMAMPUAN BERARGUMEN PESERTA DIDIK
}

\section{EFFECTIVENESS OF GUIDED INQUIRY BASED SCIENCE TEACHING MATERIALS TO IMPROVE STUDENT ARGUMENT SKILLS}

\author{
Deni Apriana Senjaharmini ${ }^{1}$, A Wahab Jufri ${ }^{1,2}$, Jamaluddin ${ }^{1,2}$ \\ ${ }^{1}$ Program Studi Magister Pendidikan IPA, Universitas Mataram, Mataram, Indonesia; \\ ${ }^{2}$ Program Studi Pendidikan Biologi, Jurusan Pendidikan MIPA, FKIP, Universitas Mataram, Mataram, Indonesia; \\ *Email: dhesenja487@gmail.com
}

Diterima: 15 Juli 2019. Disetujui: 15 Juli 2019. Dipublikasikan: 31 Juli 2019

\begin{abstract}
Abstrak: Penelitian ini bertujuan untuk mengetahui efektifitas bahan ajar IPA berbasis inkuiri terbimbing (BAIPABIT) terhadap kemampuan berargumen peserta didik SMP. Penelitian ini dilaksanakan pada kelas VII SMP Negeri 1 Suralaga semester ganjil tahun pelajaran 2018/2019. Jumlah sampel 43 orang peserta didik yang terbagi menjadi dua kelas penelitian, kelas kontrol dan kelas eksperimen. Jenis penelitian yang digunakan adalah penelitian eksperimen semu dengan desain penelitian pretest posttest group design. Analisis data keefektifan BAIPABIT terhadap kemampuan berargumen peserta didik dengan menggunakan indeks gain ternormalisasi dan ketuntasan belajar klasikal peserta didik. Hasil penelitian menunjukkan bahwa skor N-Gain pada kelas kontrol sebesar 30,77\% dan kelas eksperimen sebesar 57,57 \% dan analisis ketuntasan klasikal menunjukkan bahwa ketuntasan klasikal kelas kontrol sebesar 33,33\% dan kelas eksperimen sebesar 72,73\%. Hal tersebut membuktikan bahwa bahan IPA berbasis inkuiri terbimbing (BAIPABIT) lebih efektif untuk meningkatkan kemampuan berargumen peserta didik SMP daripada bahan ajar yang biasa digunakan oleh guru.
\end{abstract}

Kata Kunci : bahan ajar IPA, inkuiri terbimbing, kemampuan berargumen.

Abstract: This study aims to determine the effectiveness of guided inquiry-based science teaching materials on the ability to argue junior high school students. This research was conducted in class VII of Suralaga 1 Public Middle School in the odd semester 2018/2019 academic year. The sample of 43 students was divided into two research classes: the control and the experimental classes. The research type was quasy experimental study with pretest posttest group design. The effectiveness of inquiry-based science teaching materials on students 'ability to argue was analyzed by normalized gain indexes and students' classical completeness. The results showed that the N-Gain score in the control class was $30.77 \%$ and the experimental class was $57.57 \%$. The classical completeness analysis showed that the classical completeness of the control and experimental classes were $33.33 \%$ and $72.73 \%$, respectively. In conclusion, the guided inquiry based science material is effective in improving the ability to argue junior high school students than teaching materials commonly used by teachers.

Keywords : scinceteaching materials, guided inqury, argument ability

\section{PENDAHULUAN}

Kemampuan

berargumen

adalah

kemampuan peserta didik dalam mengungkapkan kembali materi yang disertai dengan bukti-bukti atau ide-ide hingga menarik suatu kesimpulan. Kemampuan berargumen merupakan salah satu kompetensi penting yang harus dimiliki oleh peserta didik. Penguasaan konsep memiliki korelasi dengan kemampuan berargumen peserta didik [1]. Kemampuan penguasaan konsep yang tinggi akan menyebabkan baiknya argumen yang diberikan oleh peserta didik [2].

Terkait dengan kemampuan berargumen, beberapa peneliti sudah melakukan penelitian. Sebanyak $95 \%$ mahasiswa calon guru yang ada di Jurusan Pendidikan MIPA Universitas Mataram memiliki kemampuan memberikan argumen ilmiah masih rendah [3]. Dalam hasil penelitian lainnya menyatakan bahwa $97 \%$ peserta didik menganggap kemampuan berargumentasi penting dimiliki oleh peserta didik dan perlu dibelajarkan dalam kegiatan pembelajaran di dalam kelas [2]. Kemampuan berargumen penting dibelajarkan agar peserta didik lebih memahami materi, melatih rasa percaya diri dan bermanfaat di dalam dunia kerja. Selain itu, kemampuan berargumen juga penting dalam melatih peserta didik untuk lebih aktif dalam kegiatan pembelajaran, mengetahui kesulitan peserta didik dalam memahami materi, serta dapat mengungkapkan benar tidaknya konsep yang dimiliki oleh peserta didik. 
Untuk mengetahui keadaan riil di lapangan, telah dilakukan studi pendahuluan di SMPN 1 dan SMPN 2 Suralaga, yang merupakan dua sekolah negeri yang ada di Kecamatan Suralaga Kabupaten Lombok Timur. Studi pendahuluan dilaksanakan dengan analisis kurikulum. Hasil analisis kurikulum dilaksanakan melalui analisis jawaban dan butir tes dalam Penilaian Akhir Semester Bersama (PASB) serta analisis buku teks yang digunakan oleh guru. Hasil analisis jawaban peserta didik pada PASB semester ganjil tahun pelajaran 2017/2018 bahwa peserta didik SMPN 1 Suralaga memperoleh nilai rata-rata 4,22 dengan ketuntasan klasikal hanya $9 \%$. Hasil tersebut berada jauh di bawah nilai KKM dan angka ketuntasan klasikal yang sudah ditentukan, yakni KKM 65 dengan $75 \%$ angka ketuntasan klasikal. Hasil analisis butir tes PASB menunjukkan tes PASB berisi $20 \%$ soal mengukur hafalan konsep dan $80 \%$ mengukur penguasaan konsep yang meminta peserta didik untuk memberikan penjelasan terhadap suatu permasalahan yang diberikan. Analisis jawaban peserta didik pada tiap butir tes menunjukkan sebagian besar peserta didik memiliki kelemahan dalam menjawab soal yang mengukur penjelasan ilmiah peserta didik.

Kondisi tersebut didukung oleh hasil analisis buku teks yang digunakan guru. Guru di SMPN 1 Suralaga menggunakan beberapa buku teks sebagai acuan pembelajaran. Buku teks yang digunakan diantaranya adalah BSE (Buku Sekolah Elektronik), buku teks terbitan Erlangga, buku teks dan LKS terbitan Tiga Serangkai dan buku-buku pendukung kurikulum 2013 lainnya. Dari analisis beberapa buku teks yang digunakan, dalam buku tersebut rata-rata berisi penjelasan materi pelajaran yang sangat detail dan memberikan ruang bagi peserta didik untuk memperdalam penguasaan materi melalui kegiatan praktikum. Detailnya penjelasan materi dalam buku teks tersebut secara langsung melatih peserta didik untuk menghafal konsep-konsep yang ada dalam buku teks, dan guru pun mengabaikan kegiatan praktikum karena bersifat pendalaman materi dan keterbatasan alat dan bahan praktikum yang dimiliki yang sesuai dengan kebutuhan praktikum yang terdapat dalam buku teks.

Berdasarkan data dan fakta yang diperoleh dalam studi pendahuluan membuktikan bahwa rendahnya hasil belajar yang diperoleh peserta didik disebabkan oleh kegiatan pembelajaran yang tidak memfasilitasi peserta didik untuk mengembangkan kemampuan berfikirnya. Rendahnya kemampuan berfikir akan berpengaruh terhadap kemampuan berargumen peserta didik, yang pada akhirnya akan berpengaruh terhadap penguasaan konsep mereka.

Menerapkan metode ilmiah dalam pembelajaran adalah salah satu langkah dalam meningkatkan kemampuan berargumen peserta didik, dan inkuiri terbimbing adalah contoh model pembelajaran yang dalam pelaksanaannya menerapkan metode ilmiah. Langkah metode ilmiah dalam pembelajaran dapat meningkatkan kemampuan beragumen peserta didik [5]. Pendekatan saintifik dalam model pembelajaran memberikan pengaruh yang positif terhadap kemampuan berargumen peserta didik SMA [6-8]. Dalam salah satu hasil penelitian bahwa hasil belajar peserta didik dapat ditingkatkan dengan menggunakan pembelajaran yang berbasis inkuri, dimana peserta didik dapat mempraktekkan langsung apa yang dipelajari [9].

Pelajaran IPA banyak mengandung konsep abstrak yang harus dipahami oleh peserta didik, dan menjadi acuan penting bagi guru untuk mengajarkan IPA secara utuh dengan menggunakan tahapantahapan proses ilmiah yang dianjurkan di dalam Kurikulum 2013 [10]. Upaya yang dilakukan untuk mengatasi hal tersebut dapat dilakukan dengan cara mengembangkan kurikulum, meningkatkan kualitas pembelajaran, peningkatan mutu tenaga pengajar serta lingkungan yang kondusif dan memadai.

Mengembangkan kurikulum dalam hal pengembangan bahan ajar yang sesuai dengan kebutuhan peserta didik dan sesuai dengan tuntutan kurikulum sangatlah penting. Bahan ajar yang berbasis inkuiri terbimbing efektif digunakan untuk meningkatkan kemampuan berargumen peserta didik, yang memudahkan mereka dalam menemukan penyelesaian masalah, menemukan konsep yang konkrit dan membangun pola berpikir yang tinggi sesuai dengan pengalaman mereka [11]. Mengembangkan perangkat pembelajaran berupa buku ajar dan LKPD yang menggunakan model inkuri pada peserta didik SMP, dapat melatih keterampilan proses peserta didik dan dapat meningkatkan penguasaan konsep peserta didik [10]. Melalui perangkat pembelajaran IPA SMP menggunakan model inkuiri terbimbing yang dikembangkan dapat meningkatkan hasil belajar kognitif peserta didik pada materi Klasifikasi Mahluk Hidup [12]. Hal tersebut disebabkan karena melalui langkah-langkah metode ilmiah yang diterapkan dalam perangkat pembelajaran yang dikembangkan dapat melatih peserta didik membangun sendiri pengetahuan mereka melalui kegiatan penelitian dalam inkuri yang dilakukan.

Melihat permasalahan di atas, dipandang perlu dilakukan penelitian untuk mengetahui efektivitas Bahan Ajar IPA berbasis Inkuiri Terbimbing (BAIPABIT) dalam meningkatkan kemampuan berargumentasi peserta didik SMPN 1 Suralaga

\section{METODE PENELITIAN}

Penelitian ini telah dilaksanakan di SMPN 1 Suralaga tahun pelajaran 2018/2019. Sampel dalam penelitian ini terdiri dari 2 kelas yaitu kelas VII-B yang berjumlah 21 orang sebagai kelas eksperimen dan kelas VII-C yang berjumlah 23 orang sebagai kelas kontrol. 
Data peningkatan kemampuan berargumen peserta didik setelah diajarkan dengan menggunakan Bahan Ajar IPA berbasis Ikuiri Terbimbing (BAIPABIT) diperoleh dari hasil pretest dan posttest kemampuan berargumen peserta didik yang dianalisis dengan menggunakan indeks gain ternormalisasi sebagai berikut:

$$
N-\text { Gain }=\frac{S_{\text {post }}-S_{\text {kawal }}}{S_{\text {max }}-S_{\text {kawal }}} \times 100 \%
$$

Keterangan:

$\mathrm{N}$-gain = Gain ternormalisasi

$\mathrm{S}_{\text {kawal }}=$ Skor kemampuan awal

S Post $\quad=$ Skor Posttest

$\mathrm{S}_{\max } \quad=$ Skor maksimum ideal

Adapun kriteria gain ternormalisasi dapat dilihat pada Tabel 1 [11].

\section{Tabel 1. Kriteria N-gain}

\begin{tabular}{cc}
\hline N-Gain & Kategori \\
\hline N-Gain $>70 \%$ & Tinggi \\
$70 \% \geq$ N-Gain $\geq 30 \%$ & Sedang \\
N-Gain $<30 \%$ & Rendah \\
\hline
\end{tabular}

Data keefektifan Bahan Ajar IPA berbasis Inkuiri Terbimbing (BAIPABIT) dianalisis menggunakan analisis ketuntasan belajar, yakni ketuntasan belajar secara individual yang diukur berdasarkan pencapaian KKM (kriteria ketuntasan minimal) dan ketuntasan belajar klasikal yang mengukur tingkat keberhasilan ketuntasan belajar peserta didik secara menyeluruh. KKM yang digunakan sebagai acuan adalah 65. Untuk mengukur persentase ketuntasan belajar klasikal (X) dengan menggunakan rumus:

$$
\mathrm{X}=\frac{\sum \text { Siswa memperoleh nilai } \geq K K M}{\Sigma \text { siswa mengikuti tes }} \times 100 \%
$$

Ketuntasan belajar klasikal peserta didik dikategorikan berdasarkan interval kriteria ketuntasan hasil tes hasil belajar disajikan pada Tabel 2 [14]:

Tabel 2. Persentasi ketuntasan klasikal hasil belajar peserta didik

\begin{tabular}{cll}
\hline $\begin{array}{c}\text { Persentase } \\
\text { ketuntasan }\end{array}$ & \multicolumn{1}{c}{ Kategori } & \multicolumn{1}{c}{ Ket. } \\
\hline$X \geq 81 \%$ & Sangat baik & Sangat efektif \\
$61 \% \leq X \geq 80 \%$ & Baik & Efektif \\
$41 \% \leq X \geq 60 \%$ & Cukup baik & Cukup efektif \\
$21 \% \leq X \geq 40 \%$ & Kurang & Kurang efektif \\
$X \geq 20 \%$ & Sangat kurang & Sangat kurang efektif \\
\hline
\end{tabular}

\section{HASIL DAN PEMBAHASAN}

Analisis peningkatan kemampuan berargumen peserta didik menggunakan rumus NGain dari hasil pretest dan posttes yang sudah dilakukan, yang kemudian dikategorikan berdasarkan kategori N-Gain dengan nilai N-Gain < $30 \%$ berada kategori rendah, $70 \% \geq \mathrm{N}$-Gain $\geq 30 \%$ kategori sedang dan N-Gain > $70 \%$ kategori tinggi [13]. Adapun tabel hasil analisis $\mathrm{N}$-gain dapat dilihat pada Tabel 3.

Tabel 3. Analisis peningkatan kemampuan berargumen peserta didik berdasarkan nilai N-Gain

\begin{tabular}{lcccc}
\hline Kelas & Kelas & Pretest & Posttest & N-Gain \\
\hline Kontrol & VII-C & 35 & 55 & $30,77 \%$ \\
Eksperimen & VII-B & 34 & 72 & $57,57 \%$ \\
\hline \multicolumn{2}{c}{ Kategori } & & Sedang \\
\hline
\end{tabular}

Untuk mengetahui efektifitas pembelajaran menggunakan bahan ajar IPA berbasis inkuiri terbimbing (BAIPABIT) terhadap kemampuan berargumen peserta didik dianalisis menggunakan rumus persentase ketuntasan klasikal (X), dengan menghitung persentase jumlah peserta didik yang memproleh nilai di atas KKM (65). Nilai persentase ketuntasan klasikal tersebut kemudian dikategorikan menggunakan kriteria keefektifan dengan nilai persentase ketuntasan klasikal $X \geq 20 \%$ dengan kategori sangat kurang efektif, $21 \% \leq X \geq 40 \%$ kategori kurang efektif, $41 \% \leq X \geq 60 \%$ kategori cukup efektif, $61 \% \leq \mathrm{X} \geq 80 \%$ kategori efektif dan $\mathrm{X}$ $\geq 81 \%$ dengan kategori sangat efektif [14]. Hasil analisis keefektifan BAIPABIT terhadap kemampuan berargumen dapat dilihat pada Gambar 1.

72.73

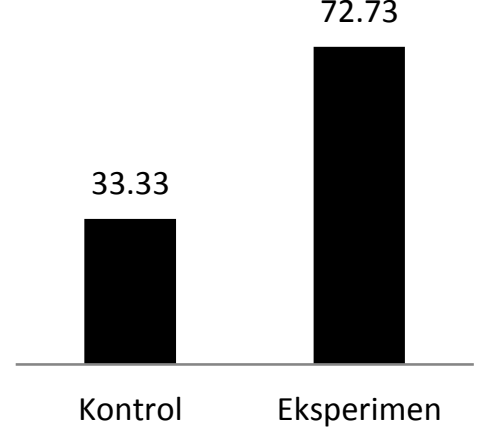

Gambar 1. Diagram persentase ketuntasan belajar peserta didik

Berdasarkan dari hasil analisis ketuntasan klasikal menunjukkan bahwa bahan ajar IPA berbasis inkuiri terbimbing (BAIPABIT) yang diterapkan di SMP Negeri 1 Suralaga dapat meningkatkan kemampuan berargumen peserta didik. Hal tersebut dilihat dari persentase ketuntasan klasikal pada kelas 
eksperimen sebesar 72,73\% dan kelas kontrol sebesar $33,33 \%$. Ini membuktikan bahwa penggunaan BAIPABIT dalam pembelajaran di kelas efektif meningkatkan kemampuan berargumen peserta didik SMP dibandingkan pembelajaran dengan buku teks yang biasa digunakan guru di SMPN 1 Suralaga. Hasil analisis ketuntasan klasikal tersebut diperkuat oleh hasil uji $\mathrm{N}$-gain dengan nilai $\mathrm{N}$-Gain sebesar $57,57 \%$ dengan kategori sedang pada kelas yang belajar menggunakan BAIPABIT.

Meningkat kemampuan berargumen peserta didik dalam penelitian ini serupa dengan penelitian yang dilakukan bahwa kemampuan berargumentasi peserta didik dapat meningkat melalui kegiatan penyelidikan ilmiah karena dalam pelaksanaannya peserta didik dilatih menyimpulkan hasil penelitian yang valid berdasarkan bukti-bukti yang didapatkan melalui penyelidikan yang dilakukan [15]. Meningkatnya kemampuan beragumen peserta didik karena mereka menemukan sendiri bukti berdasarkan hasil penyelidikan. Argumentasi adalah eksplorasi yang sistematis dari suatu konfirmasi teoritis melalui koordinasi bukti-bukti yang menggambarkan hasil observasi empiris atau hasil eksperimen tentang fenomena alam [16].

Peningkatan kemampuan berargumen disebabkan oleh bahan ajar (BAIPABIT) yang dikembangkan memiliki ciri khas yang membedakannya dengan bahan ajar lain, yaitu bahan ajar IPA berbasis inkuiri terbimbing (BAIPABIT) dimana langkah-langkah dari model inkuiri terbimbing dapat melatih kemampuan berargumen peserta didik, baik memprediksi - mengamati menjelaskan, mengklasifikasikan ataupun menginterpretasi data.

\section{KESIMPULAN}

Berdasarkan tujuan, hasil penelitian dan pembahasan dapat disimpulkan bahwa bahan ajar IPA berbasis inkuiri terbimbing (BAIPABIT) cukup efektif digunakan untuk meningkatkan kemampuan berargumen peserta didik. Terbukti dari hasil analisis ketuntasan klasikal sebesar 72,73\% kategori efektif, yang didukung oleh persentase $\mathrm{N}$-Gain kemampuan berargumen peserta didik sebesar $57,57 \%$ dengan kategori sedang. Hal tersebut menunjukkan bahwa bahan ajar IPA berbasis inkuiri terbimbing (BAIPABIT) yang dikembangkan efektif meningkatkan kemampuan beragumen peserta didik.

\section{DAFTAR PUSTAKA}

[1] Noviyani, M., Kusairi, S., \& Amin, M. (2016). Penguasan Konsep dan Kemampuan Berargumentasi Siswa SMP pada Pembelajaran IPA dengan Inkuiri Berbasis Argumen. Jurnal Pendidikan: Teori, Penelitian, dan Pengembangan, 2(7), 974-978.
[2] Wardani, A. D., Yuliati, L., \& Taufiq, A. (2016). Kemampuan argumentasi ilmiah dan pemecahan masalah fisika siswa SMA pada materi gaya dan gerak. Pros. Semnas Pend. IPA Pascasarjana UM, 1 .

[3] Jufri, A. W., Setiadi, S., \& Sripatmi, D. (2016). Scientific Reasoning Ability Of Prospective Student Teacher in The Excellence Program of Mathematics and Science Teacher Education in University of Mataram. Jurnal Pendidikan IPA Indonesia, 5(1), 69-74.

[4] Suryani, A. I., Jufri, A. W., \& Setiadi, D. (2017). Pengaruh Model Pembelajaran 5E Terintegrasi Pendekatan Saintifik Terhadap Kemampuan Literasi Sains Siswa Smpn 1 Kuripan Tahun Ajaran 2016/2017. Jurnal Pijar Mipa, 12(1).

[5] Bayuaji, P., Hikmawati, H., \& Rahayu, S. (2017). Pengaruh Model Pembelajaran Kooperatif Tipe Student Facilitator And Explaining (Sfae) Dengan Pendekatan Saintifik Terhadap Hasil Belajar Fisika. Jurnal Pijar Mipa, 12(1).

[6] Ishak, M., Jekti, D. S. D., \& Sridana, N. (2017). Pengaruh Penerapan Pendekatan Saintifik Menggunakan Model Pembelajaran Discovery Dan Kooperatif Tipe Stad Terhadap Kemampuan Berpikir Kreatif Peserta Didik SDN 13 Ampenan. Jurnal Pijar Mipa, 12(1).

[7] Nasir, M., \& Jufri, A. W. (2015). Pengembangan Perangkat Pembelajaran Model 5E untuk Meningkatkan Kemampuan Berpikir Kritis Siswa. Jurnal Penelitian Pendidikan IPA, 1(2).

[8] Jayanti, M. I., Jufri, A. W., \& Ramdani, A. (2015). Pengembangan Perangkat Model Pembelajaran Kuantum Berbasis Masalah dengan Pendekatan Saintifik. Jurnal Penelitian Pendidikan IPA, 1(2).

[9] Harjono, A., Jufri, W., \& Arizona, K. (2017). Implementasi Media Tiga Dimensi Kemagnetan Berbasis Inkuiri Melalui Strategi Kooperatif Terhadap Sikap Ilmiah Siswa. Jurnal Pendidikan Fisika dan Teknologi, 1(1), 15-23.

[10] Rinarta, I. N., Yuanita, L., \& Widodo, W. (2014). Pengembangan Perangkat Pembelajaran Model Inkuiri untuk Melatihkan Keterampilan Proses Sains dan Penguasaan Konsep Siswa SMP. Jurnal Pendidikan Fisika, 2(2). 
[11] Seprianingsih, D., \& Jufri, A. W. (2017). Pengembangan Perangkat Pembelajaran Biologi Berbasis Inkuiri Terbimbing (Ppbit) dalam Meningkatkan Kemampuan Berargumen Siswa. Jurnal Penelitian Pendidikan IPA, 3(2).

[12] Yunita, E. (2016). Pengembangan Perangkat Pembelajaran Menggunakan Model Inkuiri Terbimbing Topik Klasifikasi Makhluk Hidup di SMP. JINoP (Jurnal Inovasi Pembelajaran), 2(1), 282-292.

[13] Mashuri, M. T. (2014). Upaya Peningkatan Representasi Peserta Didik Melalui Media Animasi Submikroskopik Untuk Materi Pokok Larutan Penyangga. Media Sains, 7(1), 73-78.

[14] Jannah, A. I., \& Listyani, E. (2017). Pengembangan Bahan Ajar Pada Bahasan Himpunan Dengan Pendekatan Problem Solving Untuk Siswa Smp Kelas VII. Jurnal Pendidikan Matematika-S1, 6(3), 55-56.

[15] Marhamah, O. S., Nurlaelah, I., \& Setiawati, I. (2017). Penerapan model argument-driven inquiry (ADI) dalam meningkatkan kemampuan berargumentasi siswa pada konsep pencemaran lingkungan di kelas $\mathrm{X}$ SMA Negeri 1 Ciawigebang. Quagga: Jurnal Pendidikan dan Biologi, 9(02), 39-45.

[16] Bell, P., \& Linn, M. C. (2000). Scientific arguments as learning artifacts: Designing for learning from the web with KIE. International journal of science education, 22(8), 797-817. 